\title{
Spontaneous Pneumorrachis: A Complication of Nitrous Oxide Inhalation and Cocaine Snorting
}

\author{
Atul Vats ${ }^{1 *}$, Amit Amit ${ }^{2}$ and Ronan Dardis ${ }^{2}$ \\ ${ }^{1}$ Clinical Fellow of Neurosurgery, University Hospital Coventry and Warwickshire, UK \\ ${ }^{2}$ Consultant Neurosurgeon, University Hospital Coventry and Warwickshire, UK
}

Submission: March 13, 2018; Published: March 23, 2018

*Corresponding author: Atul Vats, Clinical Fellow of Neurosurgery, University Hospital Coventry and Warwickshire, Coventry, UK CV22DX, Tel: 07448765620; Email: vatsatul7@gmail.com

\section{Abstract}

Context: Pneumorrhachis (PR) is an uncommon condition characterized by the presence of air within the spinal canal. Usually it results following trauma or surgery involving spinal instrumentation. Spontaneous pnemorrachis has also been described in association with spontaneous pneumomediastinum or secondary to marijuana smoking and cocaine snorting.

Findings: We report a case of spontaneous pnemorrachis in a patient who was snorting cocaine along with nitrous oxide inhalation for recreation.

Conclusion: It is helpful to elicit a history of illicit drug use, particularly regarding cocaine in a case of spontaneous pneumorrhachis.

Keywords: Pnemothorax; Drug abuse; Spine non trauma

\section{Case Report}

A 19 year male came to emergency department with shortness of breath and pleuritic chest pain. He had a history of inhalation of nitrous oxide and cocaine. He denied any trauma or recent air travel. On clinical examination he was anxious and tachypneic. There was extensive crepitus over the neck and anterior chest. CT scan of the chest showed extensive subcutaneous emphysema with pneumo-mediastinum and interstitial emphysema. Traces of pnemothoraces were seen in the apices and air was seen in spinal canal at C7/T1 level (Figure 1a \& 1b). CT scan of the brain was reported to be normal. The neurological examination was entirely normal. He was managed conservatively with high flow oxygen inhalation. He improved clinically after 48 hours and was subsequently discharged for outpatients follow up.

\section{Discussion}

Spontaneous pnemorrachis is a rare entity, with one study reporting an incidence of $9.5 \%$ in a group of paediatric patient with newly diagnosed spontaneous pnemo-mediastinum [1]. Uses of Illicit stimulants such as cocaine, amphetamines, and their derivatives have been associated with development of pneumo-mediastinum [2]. Crack cocaine is most commonly associated with respiratory complications requiring hospital admission. Injections of methamphetamines have also been associated with pneumo-mediastinum and subcutaneous emphysema, along with pneumorrhachis [3]. Pneumorrhachis is classified as internal, intra-dural, external, and extradural [4]. Intradural PR is recognized by the presence of pneumocephalus without a head trauma wherein the air originates from a dural tear from a penetrating spinal injury. Traumatic external (intraspinal or extradural) PR usually recovers uneventfully; Traumatic internal PR is associated with major trauma and can be considered a severity marker [5].

Pneumorrhachis has been reported to result from the rupture of high-pressured alveoli (Macklin phenomenon) secondary to an acute increase in the transalveolar pressure gradient during a Valsalva manoeuvre. The air then may enter cervical subcutaneous tissues, mediastinum, pericardium, and epidural space, in the latter via the neural foramina and along the vascular and nerve root sheaths [6].

Of all the reported cases of spontaneous PR, four were reported to have developed neurologic signs and symptoms [7$10]$. All the cases recovered without any specific intervention.

CT scan is the imaging modality of choice for diagnosis but differentiation between internal and external PR is difficult. Spontaneous PR is usually self limiting and there are no 
established guidelines for the management of spontaneous PR. It is usually treated conservatively as the air is reabsorbed by the blood stream with no consequence. A thorough evaluation of patients presenting with clinical signs and symptoms of pneumomediastinum should include a meticulous neurologic evaluation and CT imaging of the neck and chest to assess for concurrent PR.

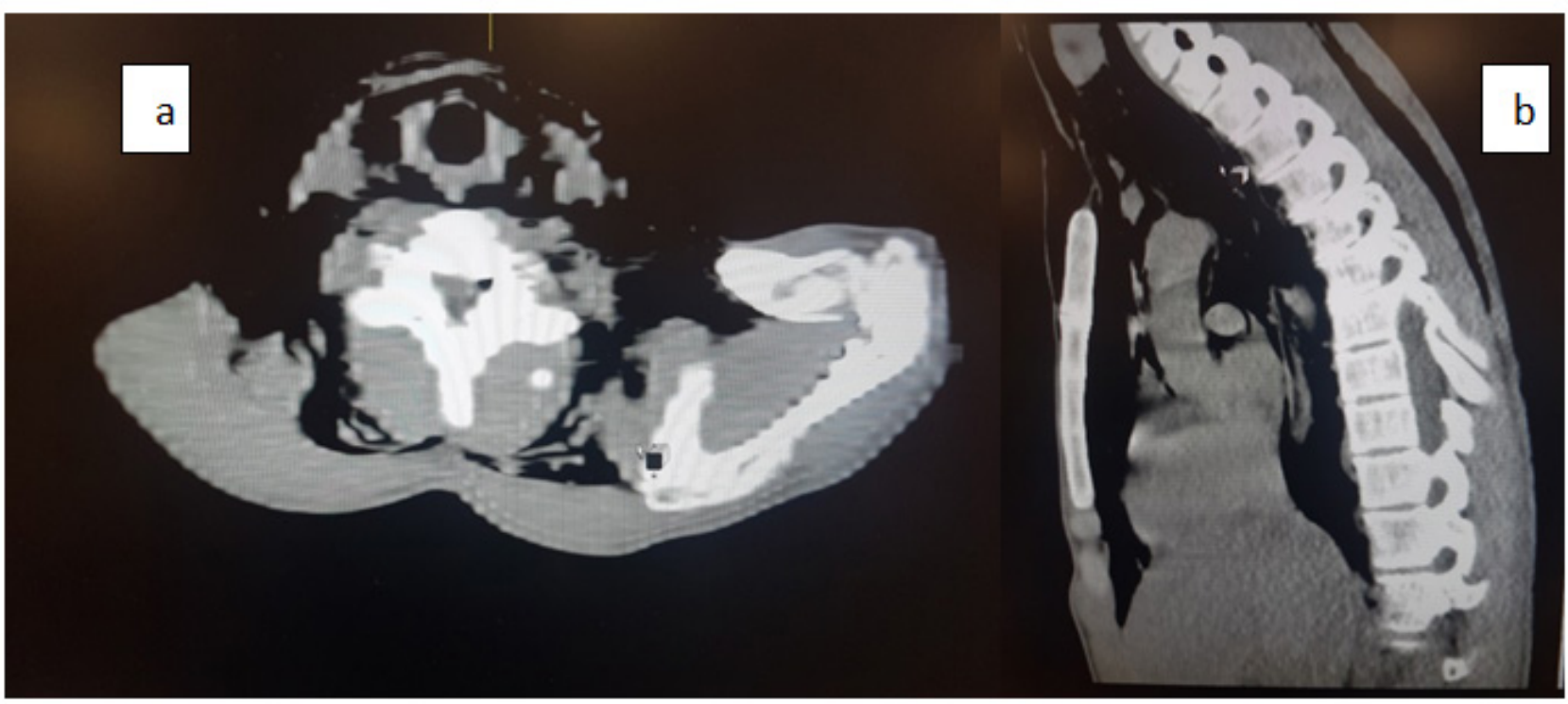

Figure 1: a) Axial view of $C 7$ vertebra with air inside the canal. b) Corresponding sagittal view showing air in $C 7$ and $T 1$ neural foraminae.

\section{Conclusion}

Pneumorrachis is a self-limiting condition and resolves without any consequences. Prompt recognition of the underlying cause is essential for management planning. It is helpful to elicit a history of illicit drug use, particularly regarding amphetamines and cocaine.

\section{References}

1. Kono T, Kuwashima S, Fujioka M, Kobayashi C, Koike K, et al. (2007) Epidural air associated with spontaneous pneumomediastinum in children: uncommon complication? Pediatr Int 49(6): 923-927.

2. Tseng W, Sutter ME, Albertson TE (2013) Stimulants and the lung: review of literature. Clin Rev Allergy Immunol 46(1): 82-100.

3. Devlin RJ, Henry JA (2008) Clinical review: major consequences of illicit drug consumption. Crit Care 12(1): 202.

4. Kara H, Akinci M, Degirmenci S, Bayir A, Ak A (2015) Traumatic pneumorrhachis: 2 cases and review of the literature. Am J Emerg Med 33(6): 861.e1-861.e3.
5. Goh BK, Yeo AW (2005) Traumatic pneumorrhachis. J Trauma 58(4): 875-879.

6. Oertel MF, Korinth MC, Reinges MH, Krings T, Terbeck S, et al. (2006) Pathogenesis, diagnosis and management of pneumorrhachis. Eur Spine J 15 Suppl 5: 636-643.

7. Song KJ, Lee KB (2009) Spontaneous extradural pneumorrhachis causing cervical myelopathy. Spine J 9(2): e16-e18.

8. Patel V, Raval G, Gavadia K (2012) Pneumothorax, pneumomediastinum, subcutaneous emphysema and pneumorrhachis as complications of common flu. Am J Case Rep 13: 198-201.

9. Song Y, Tu L, Wu J (2009) Pneumorrhachis with spontaneous pneumomediastinum and subcutaneous emphysema. Intern Med 48: $1713-1714$

10. Migeot M, Kessler R, Etxeberria Izal A, Rutgers MP, Gille M (2013) Pneumorrhachis associated with a spontaneous pneumomediastinum. Rev Neurol (Paris) 169(2): 173-174. 
This work is licensed under Creative Commons Attribution 4.0 Licens

DOI: 10.19080/JHNSS.2018.02.555592

\section{Your next submission with Juniper Publishers will reach you the below assets}

- Quality Editorial service

- Swift Peer Review

- Reprints availability

- E-prints Service

- Manuscript Podcast for convenient understanding

- Global attainment for your research

- Manuscript accessibility in different formats

( Pdf, E-pub, Full Text, Audio)

- Unceasing customer service

Track the below URL for one-step submission https://juniperpublishers.com/online-submission.php 